\title{
ANALISIS PERBANDINGAN RETURN DAN RISK PADA SAHAM SYARIAH DAN SAHAM KONVENSIONAL
}

\author{
Ruwi Cahyani ${ }^{1}$, Muhammad Andryzal Fajar ${ }^{2}$ \\ 1,2Universitas Negeri Yogyakarta, ruwicahyani98@gmail.com , andryzal_fajar@uny.ac.id
}

\begin{abstract}
ABSTRAK
Penelitian ini bertujuan untuk mengetahui perbedaan antara return dan risk pada saham syariah dan saham konvensional (studi pada Jakarta Islamic Index (JII) dan Investor33 periode Desember 2016November 2019). Populasi penelitian adalah saham syariah yang tercatat di Jakarta Islamic Index terdiri dari 30 emiten dalam setiap periode dan saham konvensional yang tercatat di indeks Investor33 yang terdiri dari 33 emiten dalam setiap periode. Sampel yang diambil sebanyak 16 saham yang tercatat di Jakarta Islamic Index dan 14 saham yang tercatat di indeks Investor33 dengan teknik pengambilan sampel menggunakan metode purposive sampling. Teknik analisis data yang digunakan adalah statistik deskriptif dan statistik inferensial dengan menggunakan uji beda dalam melakukan penarikan kesimpulan. Berdasarkan uji normalitas yang telah dilakukan didapatkan hasil bahwa data return Jakarta Islamic Index tidak berdistribusi normal sedangkan return indeks Investor33 berdistribusi secara normal dan data risk Jakarta Islamic Index dan Investor33 berdistribusi normal. Berdasarkan uji Mann Whitney $U$ didapatkan hasil nilai signifikan > 0,05 yaitu sebesar 0,088 untuk tingkat return. Uji Independent Sample T Test didapatkan nilai signifikan untuk tingkat risk $>0,05$ yaitu sebesar 0,507. Sehingga dapat disimpulkan bahwa, return dan risk pada saham syariah dan saham konvensional tidak ada perbedaan.
\end{abstract}

Kata kunci: Return, Risk, Saham Syariah, Saham Konvensional

\begin{abstract}
This study aims to determine The difference between returns and risk on Islamic stocks and conventional stocks (a study on the Jakarta Islamic Index (JII) and Investor33 for the period December 2016-November 2019). The study population is Islamic stocks listed in the Jakarta Islamic Index consisting of 30 issuers in each period and conventional shares listed in the Investor33 index which consists of 33 issuers in each period. Samples were taken as many as 16 shares listed in the Jakarta Islamic Index and 14 shares listed in the Investor33 index with a sampling technique using purposive sampling method. The data analysis technique used is descriptive statistics and inferential statistics by using a different test in drawing conclusions. Based on the normality test that has been done, the results show that the Jakarta Islamic Index return data is not normally distributed while the Investor33 index return is normally distributed and the Jakarta Islamic Index and Investor33 risk data are normally distributed. Based on the Mann Whitney $U$ test, a significant value of $>0.05$ is obtained, which is 0.088 for the rate of return. Independent Sample T Test obtained a significant value for the level of risk $>0.05$ which is equal to 0.507. So it can be concluded that, the return and risk on Islamic stocks and conventional stocks are no difference.
\end{abstract}

Keywords: Return, Risk, Sharia Shares, Conventional Shares

Naskah diterima: 29-09-2020, Naskah dipublikasikan: 30-11-2020 


\section{PENDAHULUAN}

Pasar modal adalah pasar untuk memperjualbelikan sekuritas yang umumnya memiliki umur lebih dari satu tahun, seperti saham, obligasi, dan reksa dana (Tandelin, 2017:25). Pasar modal mempunyai peran yang sangat penting baik dari sisi permintaan modal oleh perusahaan (emiten) atau dalam bahasa inggrisnya issuer maupun dalam sisi penawaran oleh pemilik modal, yaitu masyarakat yang biasa disebut dengan investor. Sepertinya, keduanya sama-sama mendapatkan keuntungan. Bahkan pasar modal dijadikan tolak ukur kemodern, artinya suatu bangsa atau negara baru berhak menyandang predikat modern kalau pasar modalnya maju (Widoatmodjo, 2015:6). Di Indonesia yang mayoritas penduduknya beragama Islam mulai dikembangkan investasi berbasis syariah, dimana investasi tersebut mengintegrasikan nilai-nilai agama yang dianut dalam kegiatan investasi dengan cara melakukan proses seleksi (screening) dalam memilih instrumen investasi. Salah satu sarana dalam berinvestasi sesuai prinsip islam adalah melalui pasar modal syariah (Syafrida dkk, 2014:196).

Pasar modal syariah merupakan kegiatan pasar modal yang tidak bertentangan dengan prinsip syariah islam di pasar modal. Pasar modal syariah mulai ada di Indonesia sejak diterbitkannya reksa dana syariah oleh PT. Danareksa Investment Management pada 3 Juli 1997. Selanjutnya Bursa Efek Indonesia (d/h Bursa Efek Jakarta) bekerjasama dengan PT. Danareksa Investment Management meluncurkan Jakarta Islamic Index pada tanggal 3 Juli 2000 yang bertujuan untuk memandu investor yang ingin menginvestasikan dananya secara syariah (www.ojk.go.id).

Salah satu instrumen investasi yang diperdagangkan di pasar modal adalah saham. Saham (stock) didefinisikan sebagai tanda penyertaan modal seseorang atau pihak (badan usaha) dalam suatu perusahaan atau perseroan terbatas (www.idx.co.id). Seorang investor dalam melakukan investasi saham harus memerhatikan indeks harga saham. Menurut Widoatmodjo (2015:121), indeks harga saham merupakan ringkasan dari dampak simultan dan kompleks atas berbagai macam faktor yang berpengaruh terutama fenomena ekonomi. Saat ini terdapat 34 indeks harga saham yang terdaftar di Bursa Efek Indonesia (BEI). Salah satu indeks harga saham tersebut adalah Jakarta Islamic Index (JII) dan indeks Investor33. Jakarta Islamic Index (JII) dan indeks Investor33 sama-sama mengukur kinerja harga saham berdasarkan tingkat likuiditas, kapitalisasi pasar, dan memiliki kesamaan untuk jadwal evaluasi indeks yaitu bulan Mei dan November.

Seorang investor dalam melakukan investasi harus memerhatikan dua hal yaitu, return dan risk. Menurut Tandelin (2017:113), return merupakan salah satu faktor yang memotivasi investor untuk berinvestasi dan juga merupakan imbalan atas keberanian investor menanggung risiko atas investasi yang dilakukannya. Berdasarkan year on year (YoY) return antara indeks Investor33 dan Indeks Harga Saham Gabungan (IHSG) tahun 2016-2019 diperoleh hasil bahwa, indeks Investor33 mengalami penurunan persentase return pada tahun 2016 ke 2017 dan 2017 ke 2018. Sementara untuk tahun 2018 ke 2019 mengalami kenaikan. Persentase return indeks Investor33 untuk tahun 2017 dan 2019 lebih besar bila dibandingkan dengan persentase return Indeks Harga Saham Gabungan (IHSG). Namun untuk tahun 2016 dan 2018 persentase return Indeks Harga Saham Gabungan (IHSG) lebih besar dari indeks Investor33. Berikut disajikan persentase return untuk tahun 2016 - 2019.

Tabel 1. Year on Year (YoY) Returns

\begin{tabular}{|c|c|c|}
\hline Tahun & Investor33 & IHSG \\
\hline 2019 & $3.8 \%$ & $1.7 \%$ \\
\hline 2018 & $-2.7 \%$ & $-2.5 \%$ \\
\hline 2017 & $25.7 \%$ & $20.0 \%$ \\
\hline 2016 & $13.8 \%$ & $15.3 \%$ \\
\hline
\end{tabular}

Sumber: www.idx.co.id (fact-sheet Investor33)

Berdasarkan year on year (YoY) return antara Jakarta Islamic Index (JII) dan Indeks Harga Saham Gabungan (IHSG) diperoleh hasil bahwa, tingkat persentase return Jakarta Islamic Index (JII) mengalami penurunan pada tahun 2016 ke 2017 dan 2017 ke 2018 tetapi mengalami kenaikan pada tahun 2018 ke 2019. Persentase return Jakarta Islamic Index (JII) pada tahun 2019 lebih tinggi bila dibandingkan dengan Indeks Harga Saham Gabungan (IHSG). Sementara persentase return Jakarta 
Islamic Index (JII) tahun 2016-2018 lebih rendah dibandingkan dengan Indeks Harga Saham Gabungan (IHSG). Nilai persentase return tersebut terdapat pada tabel 2 yaitu sebagai berikut:

Tabel 2. Year on Year (YoY) Returns

\begin{tabular}{|c|c|c|}
\hline Tahun & JII & IHSG \\
\hline 2019 & $1.9 \%$ & $1.7 \%$ \\
\hline 2018 & $-9.7 \%$ & $-2.5 \%$ \\
\hline 2017 & $9.4 \%$ & $20.0 \%$ \\
\hline 2016 & $15.0 \%$ & $15.3 \%$ \\
\hline
\end{tabular}

Sumber: www.idx.co.id (IDX Stock Index Handbook V1.0)

Risiko sering dihubungkan dengan penyimpangan atau deviasi dari outcome yang diterima dengan yang diekspektasi (Hartono, 2014:285). Menurut Prasetyo (2018:312), saham merupakan instrumen investasi dengan risiko yang tinggi, untuk mengurangi risiko biasanya seorang investor disarankan membeli saham yang mempunyai likuiditas tinggi. Berdasarkan penelitian terdahulu terkait dengan return dan risk yang dilakukan oleh Muthoharoh dan Sutapa (2014) didapatkan hasil bahwa, terdapat perbedaan return dan risk saham di ISSI dan IHSG. Sementara penelitian yang dilakukan oleh Kasanah \& Worokinasih (2018) didapatkan hasil bahwa, return dan risk pada saham syariah dan saham konvensional tidak terdapat perbedaan signifikan.

Pertumbuhan investor di Indonesia berdasarkan Single Investor Identification (SID) terus mengalami peningkatan mulai dari tahun 2016 sebesar 894.116, 2017 sebesar 1.122.668, 2018 sebesar 1.619.372, dan 2019 sebesar 2.484.354 (data KSEI tahun 2017, 2018, dan 2019 di www.ksei.co.id). Peningkatan jumlah investor tersebut menunjukkan bahwa kinerja pasar modal Indonesia berkembang dengan baik. Sehingga mampu menarik para investor untuk melakukan investasi.

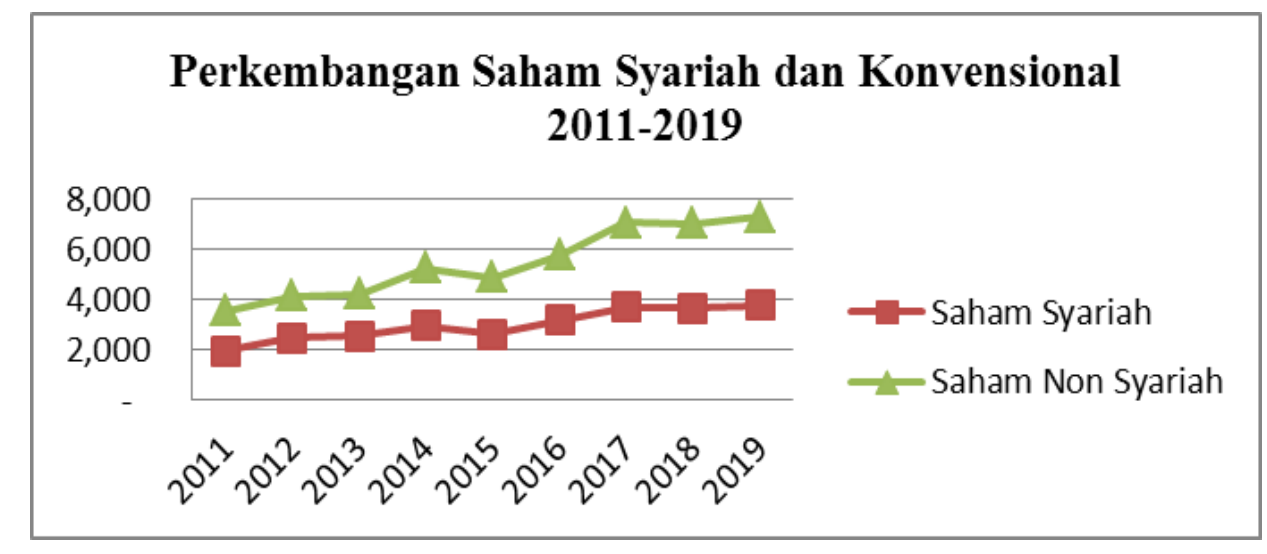

Gambar 1. Perkembangan Saham Syariah dan Saham Konvensional Berdasarkan Tingkat Kapitalisasi pasar Sumber: www.ojk.go.id/ (data diolah)

Berdasarkan gambar grafik diatas menunjukkan bahwa perkembangan investasi pada saham konvensional lebih berkembang bila dibandingkan dengan saham syariah. Perkembangan saham ini dilihat berdasarkan tingkat kapitalisasi pasar pada saham syariah dan saham konvensional. Kapitalisasi pasar merupakan nilai pasar dari saham yang diterbitkan oleh emiten. Kapitalisasi pasar yang besar umumnya menjadi salah satu daya tarik para investor dalam memilih saham (Taslim \& Wijayanto, 2016:3). Perkembangan pertumbuhan saham konvensional yang lebih tinggi dari saham syariah tersebut belum tentu dapat memberikan hasil return dan risk yang sama. Berdasarkan latar belakang, diperlukan perbandingan perbedaan antara return dan risk saham syariah dan saham konvensional. Penelitian ini bertujuan untuk mengetahui perbedaan antara return dan risk pada saham Syariah dan saham konvensional pada Jakarta Islamic Index (JII) dan Investor33. 


\section{KAJIAN LITERATUR \\ Pasar Modal}

Pasar modal (capital market) merupakan pasar yang memperjualbelikan berbagai instrumen keuangan jangka panjang atau efek (Karmila \& Ernawati, 2015:3). Menurut Zulfikar (2016:9-10), pasar modal dibedakan menjadi 2 yaitu:

1) Pasar Perdana (Primary Market)

Pasar perdana adalah penawaran saham pertama kali dari emiten kepada para pemodal selama waktu yang ditetapkan oleh pihak penerbit (issuer) sebelum saham tersebut diperdagangkan di pasar sekunder.

2) Pasar Sekunder (Secondary Market)

3) Pasar sekunder adalah tempat terjadinya transaksi jual beli saham diantara investor setelah melewati masa penawaran saham di pasar perdana dalam waktu selambat-lambatnya 90 hari setelah ijin emisi diberikan maka efek tersebut harus dicatatkan ke bursa.

\section{Pasar Modal Syariah}

Pasar modal syariah merupakan kegiatan pasar modal yang tidak bertentangan dengan prinsip syariah islam di pasar modal (www.ojk.co.id). Pasar modal syariah sebagai bagian dari pasar modal memiliki peranan penting dalam pertumbuhan perekonomian nasional. Salah satu peranan pasar modal syariah yaitu sebagai sarana pendanaan alternatif bagi perusahaan yang membutuhkan modal di samping pendanaan melalui perbankan syariah. Pasar modal syariah menawarkan beberapa keunggulan, salah satunya adalah kemampuan dalam menyediakan modal jangka panjang dengan jumlah tanpa batas. (Fajar, 2019:390)

Berdasarkan Fatwa DSN-MUI No: 40/DSN-MUI/X/2003, Prinsip syariah di bidang pasar modal yaitu:

1. Pasar Modal beserta seluruh mekanisme kegiatannya terutama mengenai emiten, jenis efek yang diperdagangkan dan mekanisme perdagangannya dipandang telah sesuai dengan syariah apabila telah memenuhi prinsip-prinsip syariah.

2. Suatu efek dipandang telah memenuhi prinsip-prinsip syariah apabila telah memperoleh pernyataan kesesuaian syariah.

Berdasarkan www.idx.co.id, terdapat 17 fatwa DSN-MUI yang berhubungan dengan pasar modal syariah. Sementara tiga fatwa MUI yang menjadi dasar pengembangan pasar modal syariah yaitu:

1) Fatwa DSN-MUI No: 20/DSN-MUI/IV/2001 tentang Pedoman Pelaksanaan Investasi untuk Reksa Dana Syariah

2) Fatwa DSN-MUI No: 40/DSN-MUI/X/2003 tentang Pasar Modal dan Pedoman Umum Penerapan Prinsip Syariah di Bidang Pasar Modal.

3) Fatwa DSN-MUI No: 80/DSN-MUI/III/2011 tentang Penerapan Prinsip Syariah dalam Mekanisme Perdagangan Efek Bersifat Ekuitas di Pasar Reguler Bursa Efek.

\section{Saham}

Berdasarkan www.idx.co.id, saham (stock) didefinisikan sebagai tanda penyertaan modal seseorang atau pihak (badan usaha) dalam suatu perusahaan atau perseroan terbatas. Menurut Karmila \& Ernawati (2015:71-72) saham dibedakan menjadi dua yaitu:

1) Saham Biasa (common stock)

Saham biasa merupakan jenis efek yang paling sering dipergunakan oleh emiten untuk memperoleh dana dari masyarakat.

2) Saham Preferen

3) Saham preferen merupakan gabungan (hybrid) antara obligasi dan saham biasa, artinya memiliki karakteristik obligasi juga memiliki karakteristik saham biasa. 


\section{Saham Syariah}

Berdasarkan www.idx.co.id, saham syariah merupakan efek berbentuk saham yang tidak bertentangan dengan prinsip syariah di pasar modal. Berdasarkan www.ojk.co.id, suatu saham dapat dikatagorikan sebagai saham syariah jika saham tersebut diterbitkan oleh:

1) Emiten dan Perusahaan Publik yang secara jelas menyatakan dalam anggaran dasarnya bahwa kegiatan usaha Emiten dan Perusahaan Publik tidak bertentangan dengan Prinsip-prinsip syariah.

2) Emiten dan Perusahaan Publik yang tidak menyatakan dalam anggaran dasarnya bahwa kegiatan usaha Emiten dan Perusahaan Publik tidak bertentangan dengan Prinsip-prinsip syariah, namun memenuhi kriteria sebagai berikut:

a) kegiatan usaha tidak bertentangan dengan prinsip syariah sebagaimana diatur dalam peraturan IX.A.13, yaitu tidak melakukan kegiatan usaha:

(1) perjudian dan permainan yang tergolong judi;

(2) perdagangan yang tidak disertai dengan penyerahan barang/jasa;

(3) perdagangan dengan penawaran/permintaan palsu;

(4) bank berbasis bunga;

(5) perusahaan pembiayaan berbasis bunga;

(6) jual beli risiko yang mengandung unsur ketidakpastian (gharar) dan/atau judi (maisir), antara lain asuransi konvensional;

(7) memproduksi, mendistribusikan, memperdagangkan dan/atau menyediakan barang atau jasa haram zatnya (haram li-dzatihi), barang atau jasa haram bukan karena zatnya (haram li-ghairihi) yang ditetapkan oleh DSN-MUI; dan/atau, barang atau jasa yang merusak moral dan bersifat mudarat;

(8) melakukan transaksi yang mengadung unsur suap (risywah);

b) rasio total hutang berbasis bunga dibandingkan total ekuitas tidak lebih dari $82 \%$, dan

c) rasio total pendapatan bunga dan total pendapatan tidak halal lainnya dibandingkan total pendapatan usaha dan total pendapatan lainnya tidak lebih dari $10 \%$.

\section{Indeks Harga Saham}

Indeks harga saham merupakan angka yang tersusun dengan hitungan tertentu sehingga menghasilkan trend (Zulfikar, 2016:76). Di Bursa Efek Indonesia (BEI) terdapat 34 indeks harga saham. Klasifikasi indeks harga saham yang ada di BEI berdasarkan IDX Stock Index Handbook V1.0 tahun 2019, yaitu sebagai berikut: Indeks Headline, Indeks Sector, Indeks Thematik, Indeks Factor.

\section{Jakarta Islamic Index (JII)}

Jakarta Islamic Index dimaksudkan sebagai tolak ukur untuk mengukur kinerja investasi pada saham dengan basis syariah dan diharapkan dapat meningkatkan kepercayaan investor untuk berinvestasi secara syariah (Tandelin, 2017:97). Berdasarkan IDX Stock Index Handbook V1.0 (2019), jadwal evaluasi Jakarta Islamic Index (JII) setiap 6 bulan yaitu bulan Mei dan November. Basis tanggal Jakarta Islamic Index (JII) yaitu tanggal 2 Januari 1995, dengan nilai indeks sebesar 100 .

Berdasarkan www.idx.co.id, adapun kriteria likuiditas yang digunakan dalam menyeleksi 30 saham syariah yang menjadi konstituen Jakarta Islamic Index (JII) adalah sebagai berikut:

1) Saham syariah yang masuk dalam konstituen Indeks Saham Syariah Indonesia (ISSI) telah tercatat selama 6 bulan terakhir.

2) Dipilih 60 saham berdasarkan urutan rata-rata kapitalisasi pasar tertinggi selama 1 tahun terakhir.

3) Dari 60 saham tersebut, kemudian dipilih 30 saham berdasarkan rata-rata nilai transaksi harian di pasar regular tertinggi.

4) 30 saham yang tersisa merupakan saham terpilih. 


\section{Investor33}

Berdasarkan www.idx.co.id, Investor33 adalah indeks yang mengukur kinerja harga dari 33 saham yang dipilih dari 100 (seratus) perusahaan tercatat terbaik versi Majalah Investor yang dipilih berdasarkan kapitalisasi pasar, likuiditas transaksi dan fundamental serta rasio keuangan. Berdasarkan Fact Sheet Investor33 yang diambil dari www.idx.co.id, peluncuran indeks saham ini dilakukan pada tanggal 21 Maret 2014, nilai dasar dari indeks saham Investor33 yaitu 100, dan data dasar indeks saham Investor33 adalah 30 Desember 2008.

Kriteria pemilihan saham Investor33 berdasarkan Fact Sheet Indeks Investor33 yang diambil dari www.idx.co.id, yaitu sebagai berikut:

1) Perusahaan telah terdaftar di BEI untuk setidaknya 12 bulan;

2) Perusahaan merilis laporan keuangannya secara tepat waktu;

3) Perusahaan tidak memperoleh kerugian atau penolakan pendapat dari akuntan publik;

4) Perusahaan tidak melaporkan kerugian pada tahun penilaian;

5) Ekuitas perusahaan tidak kurang dari 50 miliar dan positif dalam 24 bulan terakhir;

6) Saham diperdagangkan secara aktif: diperdagangkan setiap hari selama 10 minggu terakhir , kecuali penangguhan;

7) Saham ini memiliki lebih dari 300 pemegang saham;

8) Free float saham tidak kurang dari $20 \%$.

\section{Return}

Return merupakan salah satu faktor yang memotivasi investor untuk berinvestasi dan juga merupakan imbalan atas keberanian investor menanggung risiko atas investasi yang dilakukannya (Tandelin, 2017:113). Menurut Tandelin (2017:114), return investasi terdiri atas dua komponen utama, yaitu:

1) Yield merupakan komponen return yang mencerminkan aliran kas atas pendapatan yang diperoleh secara periodik dari suatu investasi.

$$
\text { Yield }=\frac{\mathrm{Dt}}{\mathrm{Pt}-1}
$$

Sumber: Hartono (2014:265)

2) Capital gain merupakan kenaikan atau (penurunan) harga suatu surat berharga (bisa saham maupun surat utang jangka panjang), yang bisa memberikan keuntungan (kerugian) bagi investor.

$$
\text { Capital Gain }=\frac{\mathrm{Pt}-\mathrm{Pt}-1}{\mathrm{Pt}-1}
$$

Sumber: Hartono (2014:264)

Keterangan:

$\begin{array}{ll}\text { Pt } & =\text { harga investasi sekarang } \\ \text { Pt-1 } & \text { =harga investasi periode yang lalu }\end{array}$

\section{Risk}

Risiko merupakan kemungkinan perbedaan antara return aktual yang diterima dengan return harapan (Tandelin, 2017:114). Sementara Widoatmodjo (2015:215), risiko merupakan penyimpangan dari penghasilan yang diharapkan (ER/expected return). Berdasarkan www.idx.co.id, saham sebagai instrumen investasi memiliki risiko antara lain:

1) Capital Loss

Merupakan kebalikan dari capital gain, yaitu suatu kondisi dimana investor menjual saham lebih rendah dari harga beli. 
2) Risiko Likuidasi

Perusahaan yang sahamnya dimiliki, dinyatakan bangkrut oleh pengadilan, atau perusahaan tersebut dibubarkan.

Penyimpangan dapat dihitung dengan standar deviasi (SD), dengan rumus:

$$
\begin{aligned}
& S D=\sqrt{\frac{\sum_{i=1}^{n} f_{i} \cdot(\mathrm{Xi}-\bar{X})^{2}}{n-1}} \text { untuk n sampel kecil, } \mathrm{n} \leq 30 \\
& S D=\sqrt{\frac{\sum_{i=1}^{n} f_{i} \cdot(\mathrm{xi}-\bar{X})^{2}}{n}} \text { untuk n sampel besar, } \mathrm{n}>30
\end{aligned}
$$

Sumber: Hidayatullah (2015:22)

\section{PENGEMBANGAN HIPOTESIS \\ Return}

Menghitung return saja untuk suatu investasi tidaklah cukup. Risiko dari investasi juga perlu diperhitungkan. Return dan risiko mempunyai hubungan yang positif, semakin besar risiko yang harus ditanggung, semakin besar return yang harus dikompensasikan (Hartono, 2014:285). Berdasarkan penelitian terdahulu terkait dengan return yang dilakukan oleh Muthoharoh dan Sutapa (2014) didapatkan hasil bahwa, terdapat perbedaan return saham di ISSI dan IHSG. Sementara penelitian yang dilakukan oleh Kasanah \& Worokinasih (2018) didapatkan hasil bahwa, tingkat return pada saham syariah dan saham konvensional tidak terdapat perbedaan signifikan. Penelitian sejenis yang dilakukan oleh Rosyida dan Mawardi (2015) menunjukkan hasil tidak ada perbedaan yang signifikan dalam tingkat pengembalian pada saham syariah dan saham non syariah. Hasil penelitian yang dilakukan oleh Prasetyo (2018), juga menunjukkan hasil tidak ada perbedaan signifikan dalam tingkat return pada saham syariah dan non syariah.

Ho: Tidak ada perbedaan return antara Jakarta Islamic Index (JII) dan indeks Investor33.

Ha: Ada perbedaan return antara Jakarta Islamic Index (JII) dan indeks Investor33.

\section{Risk}

Berdasarkan penelitian terdahulu terkait dengan risk yang dilakukan oleh Fadillah (2010) didapatkan hasil bahwa, terdapat perbedaan statistik signifikan pada risiko antara indeks saham syariah dan konvensional selama tahun 2008-2009. Sementara penelitian yang dilakukan oleh Lestari (2013) didapatkan hasil bahwa, risk saham tidak terdapat perbedaan antara saham syariah dan saham konvensional. Selanjutnya penelitian sejenis yang dilakukan oleh Kasanah \& Worokinasih (2018) didapatkan hasil yaitu tingkat risk tidak terdapat perbedaan signifikan pada saham syariah dan saham konvensional. Penelitian sejenis yang dilakukan oleh Rosyida dan Mawardi (2015) juga menunjukkan hasil bahwa tidak ada perbedaan yang signifikan untuk tingkat risiko pada saham syariah dan saham non syariah.

Ho: Tidak ada perbedaan risk antara Jakarta Islamic Index (JII) dan indeks Investor33.

Ha: Ada perbedaan risk antara Jakarta Islamic Index (JII) dan indeks Investor33. 


\section{JURNAL AKUNTANSI, Vol. 9, No. 2 November (2020)}

\section{Kerangka Berfikir}

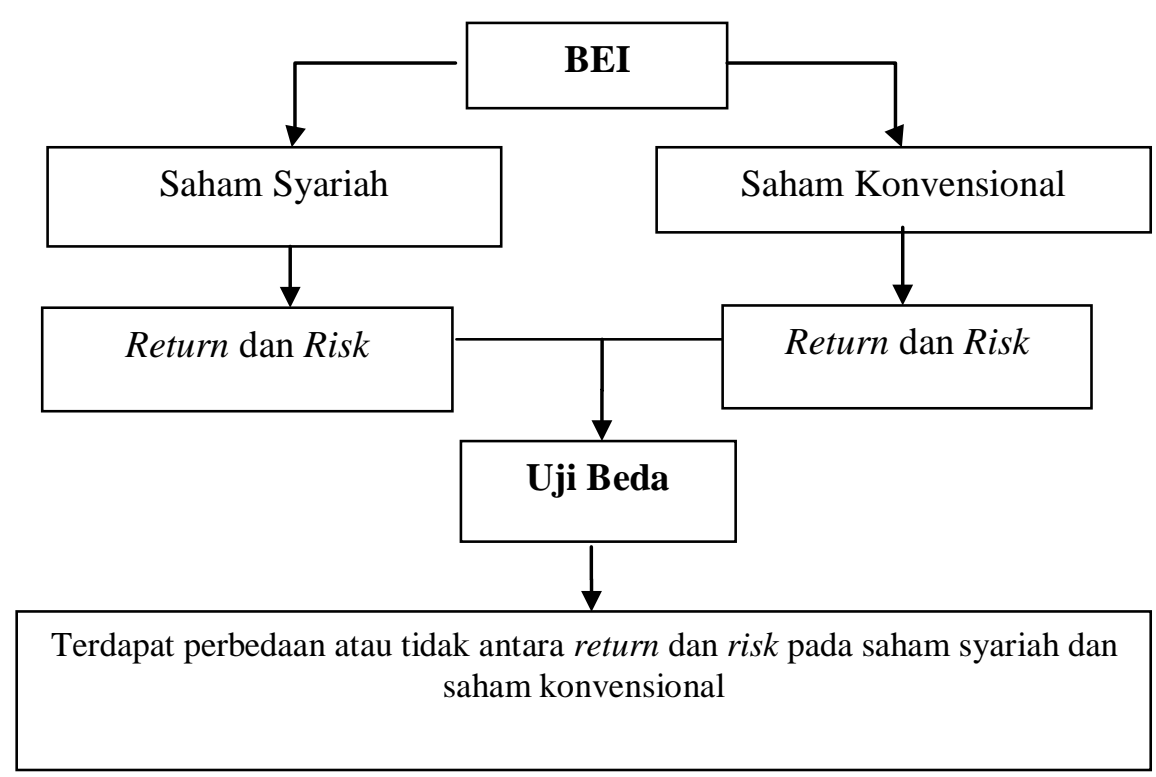

Gambar 2. Kerangka Berfikir Perbandingan Return dan Risk Saham Syariah dan Konvensional

\section{METODE PENELITIAN}

Jenis penelitian adalah penelitian komparatif, dengan membandingkan return dan risk saham pada Jakarta Islamic Index (JII) dan Investor33. Penelitian ini menggunakan metode deskriptif. Variabel yang digunakan dalam penelitian ini adalah return dan risk

Populasi dalam penelitian ini adalah saham syariah yang tercatat di Jakarta Islamic Index terdiri dari 30 emiten dalam setiap periode dan saham konvensional yang tercatat di indeks Investor33 yang terdiri dari 33 emiten dalam setiap periode. Sampel dalam penelitian ini adalah 16 saham yang tercatat di Jakarta Islamic Index (JII) dan 14 saham yang tercatat di indeks Investor33 dalam kurun waktu Desember 2016-November 2019. Teknik pengambilan sampel yang dilakukan dalam penelitian ini adalah purposive sampling. Berikut kriteria pemilihan sampel dalam penelitian ini yaitu:

1. Saham Syariah (Jakarta Islamic Index)

a. Perusahaan yang masuk ke dalam indeks saham Jakarta Islamic Index (JII) periode Desember 2016-November 2019.

b. Perusahaan tersebut konsisten masuk ke dalam indeks saham Jakarta Islamic Index (JII) selama periode penelitian.

c. Saham perusahan yang terdapat di Jakarta Islamic Index tidak tercatat dalam indeks Investor33.

d. Perusahaan tersebut tidak melakukan stock split dan reverse stock selama periode penelitian

2. Saham Konvesional (Indeks Investor33)

a. Perusahaan yang masuk ke dalam indeks Investor33 periode Desember 2016-November 2019.

b. Perusahaan tersebut konsisten masuk ke dalam indeks Investor33 selama periode penelitian.

c. Perusahaan yang sudah dicatat dalam daftar saham Jakarta Islamic Index (JII) tidak dicatat kembali di indeks Investor33.

d. Perusahaan tersebut tidak melakukan stock split dan reverse stock selama periode penelitian 
Teknik pengumpulan data dalam penelitian ini adalah teknik dokumentasi. Jenis data dalam penelitian ini adalah data sekunder. Data sekunder yang digunakan dalam penelitian ini yaitu data mengenai harga saham penutupan (closing price) bulanan dari website https://finance.yahoo.com/ periode Desember 2016-November 2019 dan data perusahaan yang masuk dalam kategori Jakarta Islamic Index dan indeks Investor33 yang diperoleh dari website http://idx.co.id. Penelitian ini akan menggunakan uji beda Independent Sample T-Test apabila datanya berdistribusi normal, namun jika datanya tidak berdistribusi normal maka akan digunakan uji beda Mann Whitney U.

\section{HASIL DAN PEMBAHASAN \\ Statistik deskriptif}

Tabel 3. Hasil Uji Statistik Deskriptif

\begin{tabular}{|l|r|r|r|}
\hline & $\begin{array}{l}\text { Minimu } \\
\text { m }\end{array}$ & $\begin{array}{c}\text { Maksimu } \\
\text { m }\end{array}$ & \multicolumn{1}{c|}{$\begin{array}{c}\text { Rata- } \\
\text { rata }\end{array}$} \\
\hline Return Jakarta Islamic Index & 0,03032 & 0,01226 & 0,00228 \\
& 0,01398 & 0,02570 & 0,00633 \\
Return indeks Investor33 & 0,04527 & 0,13989 & 0,08883 \\
& 0,04106 & 0,14450 & 0,09669 \\
Risk Jakarta Islamic Index & &
\end{tabular}

Sumber: Data Diolah

Berdasarkan tabel 3 diatas menunjukkan nilai rata-rata return Jakarta Islamic Index sebesar 0,00228 atau $-0,2 \%$ dan rata-rata return indeks Investor33 sebesar 0,00633 atau 0,6\%. Dari kedua indeks diatas return tertinggi terdapat di indeks Investor33 sementara return terendah berada di Jakarta Islamic Index.

Berdasarkan hasil uji statistik deskriptif diatas menunjukkan nilai rata-rata risk Jakarta Islamic Index sebesar 0,08883 atau 9\% dan rata-rata indeks Investor33 sebesar 0,09669 atau 10\%. Dari kedua indeks diatas risk tertinggi berada di indeks Investor33 sementara risk terendah berada di Jakarta Islamic Index.

\section{Statistik Inferensial Uji Normalitas}

Tabel 4. Hasil Uji Normalitas

\begin{tabular}{|c|c|c|c|}
\hline \multirow{2}{*}{$\begin{array}{c}\text { Ret } \\
\text { urn }\end{array}$} & Saham & Si & Ket. \\
\cline { 2 - 4 } & S. & 0, & $\begin{array}{c}\text { Tidak Berdistribusi } \\
\text { Normal }\end{array}$ \\
\hline \multirow{2}{*}{$k^{\text {Ris }}$} & Konvensiona & 016 & 0, \\
& Syariah & 0, & Berdistribusi Normal \\
\cline { 2 - 4 } & Konvensiona & 092 & Berdistribusi Normal \\
& 1 & 200 & Berdistribusi Normal \\
\hline
\end{tabular}

\section{Sumber: Data Diolah}

Berdasarkan tabel 4 diatas diketahui bahwa nilai signifikansi untuk return saham syariah (Jakarta Islamic Index) sebesar 0,016 dan return saham konvensional (indeks Investor33) memiliki nilai signifikansi sebesar 0,200. Nilai signifikansi Jakarta Islamic Index berada di bawah taraf signifikansi $a=0,05$ dan untuk indeks Investor33 berada di atas taraf signifikansi $a=0,05$. Sehingga dapat disimpulkan bahwa data return saham Jakarta Islamic Index tidak berdistribusi normal dan 
Investor33 berdistribusi normal. Hasil uji normalitas kedua return diatas dikarenakan terdapat data tidak berdistribusi secara normal, maka alat uji beda yang digunakan adalah uji Mann Whitney $U$.

Berdasarkan tabel 4 diatas diketahui bahwa nilai signifikansi untuk risk saham syariah (Jakarta Islamic Index) sebesar 0,092 dan untuk risk saham konvensional (Investor33) sebesar 0,200. Nilai signifikansi saham Jakarta Islamic Index dan Investor33 berdasarkan tabel diatas berada di atas taraf signifikansi $a=0,05$. Sehingga dapat disimpulkan bahwa data risk saham Jakarta Islamic Index dan Investor33 berdistribusi normal. Hasil uji normalitas kedua risk diatas menghasilkan data berdistribusi secara normal, maka alat uji beda yang digunakan adalah uji Independent Sample T Test.

\section{Uji Beda}

1) Uji Beda Mann Whitney $U$ untuk Tingkat Return

Tabel 5. Uji Beda Mann Whitney $U$

\begin{tabular}{|l|l|l|l|l|l|}
\hline & Nilai Z & Sig. & $\begin{array}{l}\text { Standar } \\
\text { Taraf } \\
\text { Sig. }\end{array}$ & Keputusan & Kesimpulan \\
\hline Return & $-1,704$ & 0,088 & 0,05 & $\begin{array}{l}\text { Ho } \\
\text { Diterima }\end{array}$ & $\begin{array}{l}\text { Tidak Ada } \\
\text { Perbedaan } \\
\text { yang } \\
\text { Signifikan }\end{array}$ \\
\hline
\end{tabular}

Sumber: Data Diolah

Berdasarkan tabel 5 diatas hasil pengolahan SPSS untuk uji beda Mann Whitney $U$ yang menguji tingkat perbedaan return saham syariah (Jakarta Islamic Index) dan saham konvensional (indeks Investor33) diperoleh hasil nilai signifikan sebesar 0,088. Nilai signifikansi uji beda Mann Whitney $U$ untuk tingkat return saham diatas menunjukkan hasil lebih besar dari taraf signifikansi sebesar 0,05 maka dapat disimpulkan bahwa Ho diterima dan Ha di tolak. Jadi return antara saham syariah dan saham konvensional tidak ada perbedaan yang signifikan.

2) Uji Beda Independent Sample T Test untuk Tingkat Risk

Tabel 6. Uji Beda Independet Sample T Test

\begin{tabular}{|l|l|l|l|l|}
\hline \multicolumn{2}{|c|}{} & \multicolumn{2}{|c|}{ Risk } & \multirow{2}{*}{ Keterangan } \\
\cline { 3 - 4 } & $\begin{array}{l}\text { Equal variances } \\
\text { assumed }\end{array}$ & $\begin{array}{l}\text { Equal variances } \\
\text { not assumed }\end{array}$ & \\
\hline $\begin{array}{l}\text { Levene's Test } \\
\text { for Equality of } \\
\text { Variances }\end{array}$ & Sig. & $\mathbf{0 , 1 0 1}$ & & Data Homogen \\
\hline $\begin{array}{l}\text { t-test for } \\
\text { Equality of } \\
\text { Means }\end{array}$ & $\begin{array}{l}\text { Sig. (2- } \\
\text { tailed) }\end{array}$ & $\mathbf{0 , 5 0 7}$ & 0,499 & $\begin{array}{l}\text { Ho diterima } \\
\text { Kesimpulan: } \\
\text { Tidak ada } \\
\text { perbedaan yang } \\
\text { signifikan }\end{array}$ \\
\hline
\end{tabular}

Sumber: Data Diolah

Uji Independent Sample T Test mensyaratkan homogenitas varian yang diujikan. Untuk mengetahui homogenitas tersebut dilakukan test Levene's Test for Equality of Variances. Hasil tes menunjukkan bahwa tingkat signifikan sebesar 0,101 > 0,05, maka dapat disimpulkan bahwa data risk saham syariah dan saham konvensional bersifat homogen. 
Data risk pada saham syariah dan saham konvensional memiliki kesamaan, maka untuk mengetahui apakah ada perbedaaan antara saham syariah dan saham konvensional untuk tingkat risk dapat dilihat pada nilai signifikan uji Independent Sample T Test. Berdasarkan tabel 6 diatas nilai signifikan menunjukkan nilai sebesar 0,507 lebih besar dari taraf signifikan sebesar 0,05, maka dapat disimpulkan bahwa Ho diterima dan Ha ditolak. Jadi antara saham syariah dan saham konvensional untuk tingkat risk tidak ada perbedaan yang signifikan.

\section{Pembahasan \\ Hipotesis Pertama}

Hipotesis pertama berkaitan dengan return yaitu Ho diterima, karena sig memiliki nilai $>0,05$ yaitu 0,088. Ini berarti bahwa return antara saham syariah dan saham konvensional tidak ada perbedaan yang signifikan. Tidak ada perbedaan return pada saham syariah dan saham konvensional juga terlihat pada hasil analisis statistik deskriptif yang menunjukkan hasil rata-rata return Jakarta Islamic Index sebesar $-0,00228$ atau $-0,2 \%$ tidak jauh berbeda dengan nilai rata-rata return indeks Investor33 sebesar 0,00633 atau 0,6\%. Tidak ada perbedaan ini disebabkan karena saham syariah merupakan bagian dari pasar modal Indonesia yang tidak terpisahkan dari pasar modal konvensional. Selain itu kriteria pemilihan saham pada Jakarta Islamic Index dan indeks Investor33 memiliki kesamaan yaitu berdasarkan kapitalisasi pasar dan tingkat likuiditas transaksi. Penelitian yang dilakukan oleh Muthoharoh dan Sutapa (2014:104), menyatakan bahwa secara konsep saham syariah dan saham konvensional antara keduanya tidak jauh berbeda. Keterkaitan investor pada saham yang terdapat di Jakarta Islamic Index juga disebabkan oleh return yang menarik dan fluktuasinya tidak berbeda jauh dengan indeks LQ45. Hal ini mengingat beberapa saham yang terdapat di Jakarta Islamic Index merupakan konstituen indeks LQ45 juga.

Penentuan return saham selain dipengaruhi oleh kinerja perusahaan juga dipengaruhi oleh faktor eksternal meliputi faktor makroekonomi dan krisis ekonomi (Kurniadi dkk, 2013:65). Rosyida \& Mawardi (2015:300) adanya faktor makroekonomi dapat mengakibatkan return pasar memiliki hubungan searah dengan return saham syariah dan saham non syariah. Hasil penelitian ini sejalan dengan penelitian terdahulu yang dilakukan oleh Rosyida \& Mawardi (2015) yang menyatakan bahwa tidak terdapat perbedaan signifikan antara return saham syariah dan saham non syariah di Bursa Efek Indonesia (BEI), hal ini dikarenakan mekanisme screening tidak memengaruhi kinerja perusahaan yang tergabung dalam saham syariah sehingga wajar jika tidak ada perbedaan return saham syariah dan non syariah.

Sementara penelitian terdahulu yang dilakukan oleh Muthoharoh dan Sutapa (2014) tidak sejalan dengan hasil penelitian ini, yang menyatakan bahwa hasil penelitiannya menunjukan terdapat perbedaan signifikan tingkat return antara saham di ISSI dan IHSG. Hasil penelitian terdahulu yang juga tidak sejalan dengan penelitian ini dilakukan oleh Lestari (2013) menyatakan bahwa, return saham terdapat perbedaan antara return saham syariah dan saham konvensional, karena sesuai dengan prinsip investasi high risk high return, low risk low return dimana semakin tinggi risiko maka semakin tinggi pula return dan sebaliknya semakin kecil risiko semakin kecil pula return. Oleh karena itu para investor di Indonesia harus hati-hati dalam melakukan investasi baik pada saham konvensional maupun saham syariah agar tidak mengalami capital loss.

\section{Hipotesis Kedua}

Hipotesis kedua berkaitan dengan risk yaitu Ho diterima, karena sig memiliki nilai > 0,05 yaitu 0,507. Ini berarti bahwa risk antara saham syariah dan saham konvensional tidak ada perbedaan yang signifikan. Tidak ada perbedaan pada saham syariah dan saham konvensional untuk tingkat risk juga terlihat pada hasil rata-rata risk Jakarta Islamic Index sebesar 0,08883 atau 9\% tidak jauh berbeda dengan nilai rata-rata risk investor33 sebesar 0,09669 atau 10\%. Tidak ada perbedaan pada saham syariah dan saham konvensional untuk tingkat risk, artinya bahwa kedua jenis saham tersebut memiliki risk yang sama-sama besar dan tidak mungkin sama-sama tidak berisiko. Prasetyo (2018), saham merupakan instrumen investasi dengan risiko yang tinggi. Tidak ada perbedaan yang signifikan antara risiko pada saham syariah dan saham non syariah bisa jadi dipengaruhi oleh kinerja perusahaan misalnya, jika dilihat melalui laporan keuangan mengenai earning per share (EPS) yang mana pada 
saat EPS perusahaan itu naik sekian persen, berarti terdapat peningkatan pada volume pendapatan, sehingga kondisi perusahaan tersebut dapat dikatakan baik (Rosyida \& Mawardi, 2015:300). Sedangkan berdasarkan penelitian yang dilakukan oleh Maharani (2017:17) menyatakan bahwa, kinerja indeks saham syariah ternyata tidak dipengaruhi oleh seberapa ketat dari proses screening apalagi kinerja saham Jakarta Islamic Index yang memiliki kebijakan screening saham lebih longgar, sehingga wajar bila tidak ada perbedaan risk pada saham syariah dan saham konvensional. Selain itu tidak ada perbedaan risk pada saham syariah dan saham konvensional ini disebabkan karena saham syariah merupakan bagian dari pasar modal Indonesia yang tidak terpisahkan dari pasar modal konvensional. Selain itu kriteria di kedua indeks tersebut dalam pemilihan saham memiliki kesamaan yaitu berdasarkan kapitalisasi pasar dan tingkat likuiditas transaksi.

Hasil penelitian ini sejalan dengan penelitian terdahulu yang dilakukan oleh Tendean dkk (2019) yang menyatakan bahwa, tidak terdapat perbedaan signifikan antara risiko saham Jakarta Islamic Index dan LQ45 penyebabnya karena terdapat faktor eksternal seperti kebijakan pemerintah, pergerakan suku bunga, fluktuasi nilai tukar mata uang, rumor dan sentimen pasar serta penggabungan perusahaan yang sama memengaruhi harga pasar saham baik saham Jakarta Islamic Index maupun LQ45. Begitu pula penelitian yang dilakukan oleh Rosyida dan Mawardi (2015) didapatkan hasil yang sama yaitu, tidak terdapat perbedaan signifikan antara risiko saham syariah dan saham non syariah di Bursa Efek Indonesia (BEI), hal ini dikarenakan mekanisme screening tidak memengaruhi kinerja perusahaan yang tergabung dalam saham syariah sehingga wajar jika tidak ada perbedaan risk saham syariah dan non syariah. Sementara penelitian terdahulu yang dilakukan oleh Murtasiyah (2018) tidak sejalan dengan hasil penelitian ini, hasil penelitian tersebut menyatakan bahwa terdapat perbedaan yang signifikan antara indeks Kompas 100 dan Jakarta Islamic Index untuk tingkat risk. Hal ini disebabkan karena risk indeks Kompas 100 dan Jakarta Islamic Index mengalami fluktuasi yang signifikan selain itu perbedaan juga disebabkan karena jenis usahanya yang syariah cenderung lebih stabil, dibandingkan usaha konvensional.

\section{PENUTUP \\ Simpulan}

Berdasarkan hasil penelitian maka dapat disimpulkan bahwa return dan risk antara saham syariah dan saham konvensional (studi pada Jakarta Islamic Index (JII) dan Investor33 periode Desember 2016-November 2019) tidak ada perbedaan. Selain itu tidak ada perbedaan return dan risk pada saham syariah dan saham konvensional ini disebabkan karena saham syariah merupakan bagian dari pasar modal Indonesia yang tidak terpisahkan dari pasar modal konvensional. Selain itu kriteria di kedua indeks tersebut dalam pemilihan saham memiliki kesamaan yaitu berdasarkan kapitalisasi pasar dan tingkat likuiditas transaksi.

\section{Saran}

Bagi penelitian selanjutnya menambah jumlah periode penelitian agar hasil yang didapatkan lebih akurat atau menggunakan periode penelitian secara harian. Menambah jumlah variabel untuk dilakukan penelitian terkait perbandingan saham syariah dan konvensional agar perbedaan tidak hanya dari sisi return dan risk. Bagi investor sebagai bahan pertimbangan dalam pengambilan keputusan terkait dengan penentuan kebijakan pemilihan investasi saham agar mendapatkan hasil yang maksimal. Bagi investor yang ingin menghindari saham yang bertentangan dengan prinsip syariah sebaiknya berinvestasi pada saham syariah mengingat return dan risk pada saham syariah dan konvensional tidak ada perbedaan. 


\section{REFERENSI}

Fadillah, R. F. N. (2010). Analisis Perbandingan Kesimbangan Risiko dan Pengembalian (risk-return tradeoff) Saham antara Jakarta Islamic Index dengan LQ45 di Bursa Efek Indonesia. Skripsi. Akuntansi Fakultas Ekonomi.

Fajar, M. A. (2019). Perkembangan Tantangan dan Peran Shariah Online Trading System (SOTS) di Pasar Modal Syariah Dalam Menghadapi Revolusi Industri 4.0. Prosiding STIE BPD Accounting Forum (SAF). Edisi 1 Desember 2019.

DSN-MUI. (2003). Fatwa Dewan Syariah Nasional Nomor: 40/DSN-MUI/X/2003 tentang Pasar Modal dan Pedoman Umum Penerapan Prinsip Syariah di Bidang Pasar Modal, diakses pada 16 April 2020 Pukul: 05.34 (https://dsnmui.or.id/katagori/fatwa/).

Hartono, J. (2014). Teori Portofolio dan Analisis Investasi. Yogyakarta: BPFE.

Hidayatullah, S. (2015). Praktikum Statistik Deskriptif. Jakarta: Penerbit Salemba Teknika.

https://finance.yahoo.com. (2020). Data Harga Saham. Dipetik Mei 14, 2020, dari https://finance.yahoo.com/

Karmila dan Ernawati, I. (2015). Pasar Modal. Yogyakarta: Penerbit Buku KTSP.

Kasanah, H. R. \& Worokinasih, S. (2018). Analisis Perbandingan Ruturn dan Risk Saham

Syariah dengan Saham Konvensional (Studi pada Jakarta Islamic Index (JII dan IDX30 Periode 2014-2016). Jurnal Administrasi Bisnis. Vol. 58 No. 2: Hal 46-55.

KSEI. (2020). KSEI News tahun 2017, 2018, dan 2019 edisi 4 - Pertumbuhan Single Investor Indentification (SID), diakses pada 17 April 2020 pukul: 07.11 ( https://www.ksei.co.id/publication/fokuss-bulletin).

Kurniadi, A., Achsani, N. A, \& Sasongko, H. (2013). Kinerja Keuangan Berbasis Penciptaan Nilai, Faktor Makroekonomi dan Pengaruhnya Terhadap Return Saham Sektor Pertanian.Jurnal Akuntansi dan Keuangan. Vol. 15 No. 2 Hal 63-74.

Lestari, A. (2013). Analisis Perbandingan Risk dan Return Saham Syariah dan Saham

Konvensional (Studi Kasus pada Indeks Saham JII dan Indeks LQ45). Skripsi. Manajemen Fakultas Ekonomi dan Ilmu Sosial.

Maharani, N. K. (2017). Analisis perbandingan kinerja saham syariah antara DJIMI, FSTE GIIS, KLSESI, dan JII. Jurnal Ekonomi dan Keuangan Islam. Vol.3 No.1 Hal 10-18

Murtasiyah, D. (2018). Analisis Perbandingan Rasio Profitabilitas, Return dan Risk Antara Saham dalam Kelompok Indeks Kompas100 dan Jakarta Islamic Index Tahun 2014-2016. Skripsi. Jurusan Ekonomi Syariah Fakultas Ekonomi dan Bisnis Islam.

Muthoharoh \& Sutapa. (2014). Perbandingan Saham Berbasis Syariah dengan Saham Konvensional sebagai Analisa Kelayakan Investasi bagi Investor Muslim. Jurnal Akuntansi Indonesia. Vol. 3 No. 2 Hal: 101-112.

Prasetyo, Y. (2018). Perbandingan Risk dan Return Investasi pada Indeks LQ 45 dengan Indeks Jakarta Islamic Index (JII). Jurnal Ekonomi Islami. Vol. 6 No.2 Hal: 311-334.

Rosyida, A. G. \& Mawardi, I. (2015). Perbandingan Tingkat Pengembalian (Return), Risiko dan Koefisien Varians Pada Saham Syariah dan Saham Non Syariah di Bursa Efek Indonesia (BEI)Periode 2011-2013. JESTT. Vol. 2 No. 4 Hal: 288-304.

Syafrida, I., Aminah, I., Waluyo, B. (2014), Perbandingan Kinerja Instrummen Investasi Berbasis Syariah dengan Konvensional pada Pasar Modal di Indonesia. Jurnal Akuntansi. Vol. VI No. 2 Hal 196-206.

Tandelin, E. (2017). Pasar Modal Manajemen Portofolio \& Investasi. Yogyakarta: Penerbit Kanisius.

Tendean, Y., P., J., Saerang, I., S., Tulung, J., E. (2019). Analisis Perbandingan Risiko Saham Jakarta Islammic Index dam LQ45 di Bursa Efek Indonesia. Jurnal EMBA. Vol. 7 No. 6 Hal 32393248.

Taslim, A \& Wijayanto, A. (2016). Pengaruh Frekuensi Perdagangan Saham, Volume

Perdagangan Saham, Kapitalisasi Pasar dan Jumah Hari Petdagangan Terhadap Return Saham. Management Analysis Journal 5 (1) Hal 1-6

Widoatmodjo, S. (2015). Pengetahuan Pasar Modal untuk Konteks Indonesia. Jakarta: Penerbit PT Alex Media Komputindo. 
www.idx.co.id. (2020). Saat ini BEI Memiliki 34 Indeks Saham. Dipetik April 4, 2020, dari https://www.idx.co.id/produk/indeks/

www.idx.co.id. (2020). Fact Sheet Index Investor33 per Desember 2019. Dipetik April 15, 2020, dari https://www.idx.co.id/data-pasar/laporan-statistik/fact-sheet-index/

www.idx.co.id. (2020). IDX Stock Index Handbook V1.0 Desember 2019. Dipetik April 7, 2020, dari https://www.idx.co.id/data-pasar/laporan-statistik/fact-book/

www.idx.co.id. (2020). Saham Syariah. Dipetik April 16, 2020, dari https://www.idx.co.id/idxsyariah/produk-syariah

www.idx.co.id. (2020). Saham yang Masuk dan keluar dalam Perhitungan Indeks JII dan Indeks Investor33. Dipetik Maret 26, 2020, dari https://www.idx.co.id/data-pasar/data-saham/indekssaham/

www.idx.co.id. (2020). Fatwa Tentang Pasar Modal Syariah. Dipetik April 4, 2020, dari https://www.idx.co.id/idx-syariah/fatwa-regulasi/

www.idx.co.id. (2020). Saham. Dipetik April 4, 2020, dari https://www.idx.co.id/produk/saham/

www.ojk.go.id. (2020). Konsep Dasar Pasar Modal Syariah dan Regulasi Pasar Modal Syariah. Dipetik April 20, 2020, dari https://www.ojk.go.id/kanal/syariah/tentang-syariah/pages/pasarmodal-syariah.aspx

www.ojk.go.id. (2020). Statistik Pasar Modal. Dipetik Juni 28, 2020, dari https://www.ojk.go.id /id/kanal/pasar modal/data-dan-statistik/statistik-pasar-modal/default.aspx

Zulfikar. (2016). Pengantar Pasar Modal dengan Pendekatan Statistika. Yogyakarta: Penerbit Deepublish. 